\title{
Didi-Huberman e a escrita: ensaiar o ver entre a imagem e o conceito
}

\section{Didi-Huberman and the writing: to try to see between the image and the concept}

Tatiane França Rangel ${ }^{1}$

\author{
Universidade Federal do Rio de Janeiro, Faculdade de Letras, Programa de Pós-Graduação em Ciência da Literatura, Rio de Janeiro, RJ, Brasil.
}

\section{RESUMO}

0 presente artigo tem como objetivo tecer uma leitura entre dois livros do filósofo e historiador da arte francês, Georges Didi-Huberman. Cascas (2017), publicado em 2011 na língua original, traz uma narrativa em primeira pessoa de uma visita do autor aos campos de concentração de Auschwitz-Birkenau. 0 segundo livro, Essayer Voir (2014), ainda sem tradução para o português, configura um processo ensaístico escrito em uma linguagem técnica e impessoal, que toca, contudo, no mesmo tema do primeiro: as imagens e a herança de Auschwitz. O diálogo entre os dois livros procura mostrar como Didi-Huberman elabora e entra em defesa de seu conceito de imagem enquanto potência dialética e força histórica, desenvolvido a partir de sua leitura de obras como a de Walter Benjamin, Primo Levi e Aharon Appelfeld. Junto a isso, o artigo desenvolve as alternativas propostas pelo autor à seguinte pergunta: de que maneira podemos resistir à barbárie?

Palavras-chave: Didi-Huberman. Imagem-dialética. Testemunho. Memória. Partilha.

\section{ABSTRACT}

The present article intends to develop an analysis between two of the books of the french philosopher and art historian, Georges Didi-Huberman. Écorces (2017), first published in 2011 in french language, is made by a first-person narrative of the author while visiting the concentration camps of Auschwitz-Birkenau. The second book, Essayer Voir (2014), shows a process of essay written in a technical and philosophical way. Its content, however, brings up the same subject of the first one: the images and the heritage from Auschwitz. The dialogue between the books shows how Didi-Huberman elaborates his concept of image as a dialectical and historical force, based on the works of Walter Benjamin, Primo Levi, and Aharon Appelfeld. Also, the article reveals how the author develops his answers to the following question: how can we resist such barbarism?

Keywords: Didi-Huberman. Dialectical image. Testimony. Memory. Sharing. 
“As mesmas flores lá fora, no campo polonês, e aqui, ao longo dos trilhos que terminam mais ao longe face ao céu, às ruínas, à cortina de álamos, sobre o solo de cinza humana". (Birkenau, Jean-Pierre Lemaire)

No campo da crítica e dos estudos filosóficos, um nome vem ganhando espaço e reconhecimento. Propositor de um intrigante movimento de pensamento, Georges Didi-Huberman ${ }^{2}$ desenvolve em suas páginas uma escrita de aproximação, sedutora, que convida à roda os leitores, com sua forma ensaística que muitas vezes passeia entre a narrativa literária e a conceituação filosófica. Autor que se debruça sobre a imagem, que entra em defesa de sua potência, Didi-Huberman tem desenvolvido um importante papel nas correntes históricas dos estudos de arte contemporâneos.

Principalmente ensaísta, como o diz Eduardo Jorge de Oliveira em seu artigo sobre o autor L'exposition comme espace de pensée, Didi-Huberman introduz em seus ensaios fotografias e imagens de obras de arte, capturadas por ele em visita a museus e a exposições ou concedidas pelos artistas. A imagem se faz presente ao leitor para que ele também se debruce sobre elas. Nesse viés, propomos como análise e recorte de sua tão vasta obra, encontrar um vértice entre dois de seus livros. Atravessados por imagens, dispondo olhar e relação, os dois textos se entrecosturam e parecem suceder um ao outro no que tange à formulação de conceitos do autor.

Em 2017, o livro Cascas é publicado pela Editora 34, primeira tradução brasileira do livro Écorces, de 2011. Em 2014, o livro Essayer Voir é, por sua vez, lançado pela Éditions de Minuit. O primeiro, um diário que testemunha a visita do autor

Filósofo, historiador e crítico da arte, Georges Didi-Huberman é atualmente professor da École de Hautes Études en Sciences Sociales, em Paris. Sua extensa produção conta com um conjunto de pouco mais de quarenta livros, nem todos publicados no Brasil. Fazem parte de sua vasta obra títulos como: La Peinture incarnée, suivi de Le chef-d'oeuvre inconnu par Honoré de Balzac (Paris: Minuit, 1985), Devant l'image. Question posée aux fins d'une histoire de l'art (Paris: Minuit, 1990), Ce que nous voyons, ce qui nous regarde (Paris: Minuit, 1992) traduzido para o português $O$ que vemos, o que nos olha (São Paulo: Editora 34 , 1998. Porto: Dafne, 2011), Devant le temps. Histoire de l'art et anachronisme des images (Paris: Minuit, 2000). ao campo de Auschwitz-Birkenau, com registros fotográficos feitos por ele. 0 segundo, uma união de dois ensaios sobre o desenrolar do "ver" diante de uma imagem - real ou virtual. Ambos tratam do tema caro a toda a obra do autor: "estar diante da imagem". Mais ainda, o que se passa quando essa vem carregada de horror, atravessada pelo pavor de um passado terrível e compartilhado em memória. Barbárie nomeada: Didi-Huberman traz à luz imagens do Holocausto.

No primeiro livro, um "eu" narra sua visita e elabora seus pensamentos em presença, enquanto sujeito que experiencia, durante a visita pelos campos. As fotografias filtram uma paisagem cinza - porque em cinzas - e de um vazio silencioso, tão mudo quanto ensurdecedor. No segundo, um filósofo distanciado molda seus conceitos com um olhar técnico e científico. Seus ensaios trazem no corpo fotografias de obras de arte sobre o Holocausto, e a sua linguagem técnica se une a elas em um duplo distanciamento de quem escreve em direção a quem lê. De um livro a outro, o que me interessa é demonstrar o percurso de pensamento de Didi-Huberman, ensaiando um jogo entre eles. Do diário ao ensaio crítico, da imagem à conceituação, e, portanto, dos nós cruzados entre os dois textos, o que esses textos nos dizem em uníssono sobre a imagem?

Começo com um Didi-Huberman da lógica do testemunho. Longe da linguagem técnica e das citações e referências que recheiam as páginas de Essayer Voir (2014), a narrativa em primeira pessoa de Cascas (2011) é escrita como um caderno de viagens, contendo registros fotográficos e relatos da visita ao campo de concentração na Polônia. Em suas páginas, o ensaísta - e narrador - busca pensar as imagens capturadas pela câmera de um DidiHuberman visitante, dialogando com os aspectos conceituais de Essayer Voir (2014) antes mesmo que eles tivessem nome. A primeira página de Cascas tonaliza o aspecto poético e narrativo do livro. 0 trecho a seguir é seguido de uma fotografia das três lascas feita pelo autor:

Coloquei três pedacinhos de casca de árvore sobre uma folha de papel. Olhei. Olhei, julgando que olhar talvez me ajudasse a ler algo jamais escrito. Olhei as três lascas como as três letras de uma escrita prévia a qualquer alfabeto. Ou, talvez, como o início de uma carta a ser escrita, mas para quem? Percebo que as dispus sobre o papel branco involuntariamente na mesma direção que segue minha língua escrita: toda "carta" começa à esquerda, ali onde enfiei minhas unhas no tronco da árvore para arrancar a casca. Em seguida, desdobra-se para a direita, 
como uma corrente funesta, um caminho acidentado: desdobramento estriado, tecido da casca precocemente rasgado. / Vemos aqui três lascas arrancadas de uma árvore, há algumas semanas, na Polônia. Três lascas de tempo. Meu próprio tempo em lascas: um pedaço de memória, essa coisa não escrita que tento ler; um pedaço de presente, aqui, sob meus olhos, sobre a página branca; um pedaço de desejo, a carta a ser escrita, mas para quem? (DIDI-HUBERMAN, 2017, p. 101).

A união da escrita em primeira pessoa com registros fotográficos de DidiHuberman torna a leitura de Cascas, seu caderno de viagens, convidativa. Virginia Woolf em seu Moments of Being (1976) afirma que o escritor é aquele que ao receber um choque é capaz de lhe dar uma forma. 0 autor, nesse pequeno livro-ensaio, é o escritor de Virginia. Diante do choque da visita aos campos, na imagem dialética entre passado e presente sob seus olhos, Didi-Huberman oferece uma forma, tomando a palavra ao aceitar a instabilidade e o temporário mutismo que as figuras de uma barbárie vencida representam. Ao narrar, ele ensaia uma maneira de conjugar seu tempo em lascas em experiência descrita, em olhar atravessado pela imagem que choca, que golpeia.

O livro inicia, portanto, com a presença em foto e em conteúdo das cascas das bétulas de Birkenau. Sobre o nome, Birkenau, o ensaísta nos explica que "Au", na língua alemã, é a denominação de lugar para a pradaria onde crescem as bétulas, ao mesmo tempo que é a terminação morfológica do alemão para designar dor. Ambos os sentidos carregados pela partícula parecem, se unidos, sintetizar a história dos campos, esses lugares "apesar do homem" [conceito de Essayer Voir] de dor pungente. Nas cascas das árvores - testemunhas da barbárie - é possível ler a história daquele ambiente. Dialéticas, tais "lascas do tempo" relatam, nos troncos, o horror de Auschwitz II.

O museu de visitação que se tornaram os campos funda um "lugar de cultura" cujos pilares se fincam no lodo de um "lugar de barbárie". Um galpão de extermínio que foi transformado em uma loja de souvenirs, o paredão das execuções que foi revestido de um novo material; muitas são as imagens que nascem do entrecruzamento dos tempos da história, e muitas são as questões que borbulham em Didi-Huberman:
Sensação dolorosa, ver os galpões do campo [...] transformados em "pavilhões nacionais", como na Bienal de Veneza, realizada justamente no momento em que atravesso o logradouro. Aqui, mais que em outros pontos, as paredes mentem: uma vez dentro do galpão, não vejo mais nenhum galpão, tendo tudo sido "remanejado" como espaço de exposição (DIDI-HUBERMAN, 2017, p. 108).

As lascas do tempo, como o campo Auschwitz-Birkenau, são representativas de um passado de barbárie, de um presente de memória e de um futuro de endereçamento. Entre o "lugar de cultura" e o "lugar de barbárie", residem imagens no vértice de tempos heterogêneos, e estar diante delas pode ser emudecedor. Como fazer, portanto, para "estar diante" do horror? Para não fechar os olhos? Para efetivamente "ver" as imagens? A resposta de Didi-Huberman é essa: "Tratase de ensaiar o ver". Passo, assim, ao segundo livro (2014). Vejamos, no encalço de seus conceitos, como o autor nos leva às imagens e como defende uma nova forma de olhar para elas (forma essa que ele mesmo ensaia em Cascas, suponho).

Essayer Voir. Em francês, a expressão causa um estranhamento já que a transitividade do verbo essayer (traduzido como "tentar") demanda uma preposição "de" antes de qualquer complemento que o siga. Logo, junto ao verbo voir (ver), a expressão gramaticalmente correta para "tentar ver" seria essayer de voir. A proposta de Didi-Huberman para nós, os que tentam ver, presente logo no título, é a de um movimento de perspectiva. Não se trataria de tentar ver, mas de algo como tentar "o" ver. Ou ainda, refinando a tradução e alinhando-a ao pensamento do autor, se trataria de "ensaiar o ver", para que seja possível ensaiar dizer e pensar ainda que a imagem nos subtraia a fala com sua força de arrebatamento.

Passemos ao corpo do ensaio. Essayer Voir inicia com uma citação de Primo Lévi, do doloroso livro "É isto um homem?", de 1947. Primo Levi é retomado ao longo do texto e usado como exemplo de escrita testemunhal, e ainda como ponto de partida para elaborar um dos conceitos chaves do livro (o de "lugar apesar de tudo"). Partindo da citação de Levi (1947), que defende a arte e a poesia como potência de resistência à barbárie, Didi-Huberman elabora:

A razão, a arte, a poesia não nos ajudam a decifrar o lugar do qual foram banidas. Mas se fazem necessárias, e mesmo vitais, para que o rasguemos: para nos lembrar que os lugares totalitários, tão eficazes que sejam, 
jamais farão desaparecer completamente essa "parcela da humanidade" - como dizia Hannah Arendt - que interromperá a obra de destruição, ainda que modesta ou lacunarmente. Isso se chama resistência, potência da sobrevida (DIDI-HUBERMAN, 2014, p. 10, grifo do autor.).

O verbo em itálico "rasgar" - déchirer em francês - está presente em grande parte das análises do autor sobre arte e imagem, em diferentes livros, e principalmente em suas considerações sobre a estética da escrita de George Bataille, em $A$ semelhança informe (2015). Esse "rasgo" no tecido autoritário que a arte tem o poder de fazer configura, destarte, uma potência de resistência, e nos faz lembrar ainda de um outro livro do autor, de $2009^{3}$. A arte e a poesia, ou a iminência do rasgo, são os vagalumes na noite, os pontos de esperança na escuridão - ou "na luz cegante dos ferozes projetores" - que fazem frente à destruição e à morte.

Didi-Huberman propõe, assim, uma forma criada pelo rasgo feito na bolha da barbárie. Essa forma "seria como um "lugar apesar de tudo": uma passagem inventada, uma brecha praticada nos impasses que os lugares totalitários querem construir, esses "lugares apesar do homem" organizados para sua aniquilação" (DIDI-HUBERMAN, 2014, p. 12). 0 primeiro conceito se vê aqui elaborado: inventar um lugar apesar de tudo, onde respire ainda uma parcela de humanidade, um lugar cuja forma é desse pequeno, mas vital, rasgo no desespero. Apesar da monstruosidade dos campos de concentração, conseguir, como o fez e o defende Primo Lévi, fazer existir um lugar outro, de outra lógica, que resiste, que permite que se sobreviva. "Uma passagem praticada na duração do mundo histórico." (2014, p. 11). Mantenhamos em mente o que Didi-Huberman defende em seu título: "ensaiar o ver". Ensaiar o "lugar apesar de tudo", nesse sentido, é o necessário para não se morrer de todo.

Aharon Appelfeld, escritor israelita e sobrevivente do Holocausto, escreve suas memórias da guerra e da fuga dos campos de concentração em seu livro Histoire d'une vie (1999). Uma passagem interessante desse livro é trazida por Didi-Huberman. Appelfeld diz que corria pela floresta, aterrorizado, com medo de ser encontrado e fuzilado, cercado das cinzas provenientes das chaminés bestiais dos campos. Na vertigem de sua fuga alucinada, faminto e sedento,

A sobrevivência dos Vagalumes (2009).
Appelfeld tromba com uma macieira de maçãs vermelhas e reluzentes. Um ponto de cor no preto e branco do caos.

Não me lembro de entrar na floresta, mas me lembro exatamente do instante quando me encontrei lá, diante de uma árvore coberta de brilhantes maçãs vermelhas. Fiquei tão estupefato que dei alguns passos para trás. Meu corpo se lembra melhor do que eu desses passos pra trás. Toda vez que faço um movimento de costas ou que retrocedo alguns passos, vejo a árvore de maçãs vermelhas (APPELFELD apud DIDI-HUBERMAN, 2014, p. 13-14).

Segundo Didi-Huberman (2014, p. 15), o menino impelido por seus instintos em sua sôfrega corrida pela floresta, encontra uma brecha ao se ver diante da macieira. Ali, afirma, a criança "cristaliza sua possibilidade de sobrevida". Sempre tateando, fragmentando, cuidadosamente analisando, o autor diz sobre o acontecimento narrado por Appelfeld que "sua arte ou poesia consistem em seguir, em completa honestidade, a potência da imagem reminiscente enquanto processo inseparável dos movimentos do corpo" (DIDI-HUBERMAN, 2014, p. 14). Existe, portanto, um corpo que testemunha, que canaliza na fluidez dos movimentos uma força de memória, de evocação do passado.

Appelfeld constrói seu "lugar apesar de tudo" e nos traz, em sua narrativa, uma imagem para compor o imaginário do Holocausto, evento histórico construído pelos registros e testemunhos dos que sofreram com ele. Segundo Didi-Huberman, Appelfeld nos conta, sem dúvida, a história de sua vida, e nos dá a ver, assim, uma parte da história que desconhecemos. No entanto, a capacidade de Appelfeld em decifrar o lugar histórico é limitada, enquanto testemunha e enquanto escritor. Didi-Huberman desenvolve: "Não existe evento puro, não esperemos então encontrar aqui a lembrança exata. Tudo se julga sobre o modo como cada um organiza, elabora e reconstrói o tempo da história" (2014, p. 17). Desse modo, para Didi-Huberman, a narrativa de Histoire d'une vie é uma reconstrução do tempo da história a partir da perspectiva de memória corporal, de onde parte a narrativa de Appelfeld.

0 conceito de testemunho hubermaniano se desenrola, assim, sempre em torno de um elemento de conflito, de controvérsias, de pontos de vista colocados em confronto. É no embate de lembranças contra lembranças, de lacunas da memória contra lacunas da narrativa, que a escrita testemunhal tece sua 
narrativa da história. 0 episódio de Appelfeld, portanto, é fundado na dialética de uma mônada e de uma montagem ${ }^{4}$. Quer dizer que seu testemunho é uma tessitura dialética a partir da imagem da macieira (a mônada) e da escrita, essa que coloca a mônada em diálogo com outras imagens. Didi-Huberman acredita que essa construção corresponderia filosoficamente ao que Walter Benjamin espera de uma prática da história articulada. Como se sabe, essa articulação está sob a observação do que Benjamin chama de "origem turbilhão".

A origem não designa o vir-a-ser disso que nasce, mas sim disso que está nascendo no vir-a-ser e no declínio. A origem é um turbilhão no rio do tornar-se, e ela provoca em seu ritmo a matéria disso que está aparecendo. A origem jamais se dá a conhecer na existência nua, evidente, factual, e seu ritmo só pode ser percebido numa dupla ótica. Ela exige ser reconhecida de um lado como restauração, como restituição, e de outro como alguma coisa que está por si própria inacabada, sempre aberta. [É portanto] a dialética que é a testemunha da origem (BENJAMIN, 2009, p. 43).

Trazer à luz as perspectivas benjaminianas é o que abre caminho para Didi-Huberman pensar a imagem na trilha da imagem dialética, a qual se constrói na esteira de uma heterogeneidade temporal. Para esclarecer melhor, significa que a imagem testemunhal de Histoire d'une vie é aquela que precisa se valer dessa origem-turbilhão, da dupla ótica temporal e não linear para que Appelfeld possa se tornar um narrador. Testemunhar e narrar são movimentos de imagens (mônadas) e de escrita (montagem). Appelfeld penteia a história de modo a acessar essa origem que está sempre em uma espécie de devir, escrevendo a história de sua vida - e uma história geral - na perspectiva de uma história aberta, dialética, em infinito desenvolvimento.

0 testemunho de Cascas, por sua vez, entra aqui em diálogo. Didi-Huberman caminha sobre a barbárie enterrada, incinerada, maquiada, e dela faz capturas e registros. Ele narra do eixo dos ecos temporais, junto a sua memória coletiva e seu pertencimento judeus, do presente de um vazio cruel dos campos que

4 Didi-Huberman se utiliza do conceito de Leibniz presente em Teodicéia (1710). "Ora, onde não há partes, não há extensão, nem figura, nem divisibilidade possíveis. E tais Mônadas são verdadeiros Átomos da Natureza e, em uma palavra, os Elementos das coisas. Indivisíveis". Trataria-se então da menor partícula da memória, a menor partícula de sentido, inquebrável, singular, indivisível. 0 que resiste apesar de, como a macieira de Appelfeld apesar do caos. berra as crueldades do passado. Comparando o processo de museu de Auschwitz ao sítio arqueológico de Birkenau, após a captura de uma foto presente na página 109 do livro, ele diz:

É bem diferente em Birkenau. Aqui, as paredes quase desapareceram. Mas a escada não mente e nos golpeia com uma força - uma força de desolação, de terror - inaudita. Tampouco o chão mente. [...] é pelo menos o que desponta quando olhamos o que resta para ver, ali onde quase tudo foi destruído: por exemplo, chão fissurado, ferido, varado, rachado. Escoriado, dilacerado, aberto. Desagregado, estilhaçado pela história, um chão que berra (DIDI-HUBERMAN, 2017, p. 109).

O testemunho, para o autor que busca ensaiar o ver, só pode se fazer em uma perspectiva temporal heterogênea, em uma imagem dialética fundada sobre uma "origem turbilhão", sempre em movimento pelos diferentes tempos simultâneos. Quer dizer que o testemunho sempre será uma parcela da história, uma porta de entrada a uma história geral em permanente construção. Uma história em constante construção e desconstrução pelas práticas de montagem entre mônadas e escritas, em um mosaico de perspectivas complementares. Ainda no encalço de Walter Benjamin, Didi-Huberman complementa que para criar o rasgo na história, para testemunhar e moldar uma forma que resista à barbárie, o homem tem que alcançar a "sobrevivência", e não somente a "sobrevida". Vejamos a citação abaixo:

O homem da sobrevida é aquele que se cala, que age por sua vida. [...] Mas o homem da sobrevivência é aquele que, ao contrário, assume a tarefa de retomar a palavra, de reinventar sua própria linguagem e de transmitir para outrem algumas imagens de pensamentos arrancadas de suas "manchas de memória". Para sobreviver à sobrevida, é preciso tornar-se aquele que nomeia (aquele que sabe dispor a discrepância de suas palavras incompletas para dizer alguma coisa de sua experiência) e aquele que mostra (aquele que sabe dispor os escombros de suas "manchas" lacunares para dar alguma coisa de sua experiência à imaginação) (DIDI-HUBERMAN, 2014, p. 20).

Chamo mais uma vez a atenção para o esforço conceitual que o ensaio em questão carrega. É a partir da constelação teórica que Didi-Huberman mobiliza 
que se torna possível engendrar as distinções entre o "homem de sobrevivência" e o "homem de sobrevida". Toda sobrevivência deve construir outros gêneros de formas para que a experiência seja discutida e transmitida. Enquanto o homem de sobrevida é aquele que resiste à morte, o homem de sobrevivência é quem toma a palavra para narrar essa resistência. Sendo assim, trata-se daquele que rompe o mutismo em sua capacidade de fazer com sua "mônada" uma "montagem", criando no silêncio do lugar presente um ponto dialético com o "lugar passado"s. Ao testemunho, à memória histórica, concerne elaborar uma relação com o presente, o qual ela divide em uma economia de "imagem dialética".

Prossigo pelos caminhos de Didi-Huberman aludindo a mais uma palavra cara ao desenvolvimento de suas considerações, a "imaginação". Para ele, a "imaginação" nos leva a deslocar e a reformular nossos pontos de vista, a partilhar da experiência do "homem de sobrevivência". Dessa maneira, se cabe ao "homem de sobrevivência" a construção da imagem dialética a partir da tomada da palavra, proporcionando, de tal modo, um novo olhar sobre a história, cabe ao leitor "imaginar" para que alcance o terreno do testemunho, partilhe da narrativa. Essa questão atravessa a visita de Didi-Huberman aos campos de Auschwitz-Birkenau, em Cascas (2017), quando, enquanto visitanteleitor e, por conta disso, narrador, preenche os espaços vazios dos campos, relê, desloca as paredes e, assim, se integra à partilha a partir do que imagina.

Sendo assim, Didi-Huberman nos fala de um "lugar apesar de tudo" que dialoga com a esfera da partilha. No pensamento que desenvolve, versa, portanto, sobre a possibilidade de partilhar uma história, de integrar o imaginário que um testemunho evoca. Para o autor, Auschwitz não seria apenas esse lugar da citação de Primo Levi, de onde a razão, a arte e a poesia foram banidas, mas

Como exemplo de Homem de sobrevivência, Didi-Huberman utiliza a figura de Simon Srebnik, nas telas de Shoah, de Claude Lanzmann. Isso porque Simon, em uma visita ao campo de concentração onde trabalhara, faz uma narrativa sobre o silêncio dos campos na atualidade e o silêncio que já existia quando os judeus eram mantidos ali. Para Didi-Huberman, o exemplo de Simon e dos testemunhos no filme de Lanzmann demonstram um esforço dialético ao "olhar a história". Shoah recusa a presença de imagens de arquivo, que seriam "redutores documentos do passado", passíveis de manipulação e refutação, para valorizar a palavra dos sobreviventes no presente da filmagem ao olhar o passado. Um fato que pode interessar Didi-Huberman escreve o ensaio "Images malgré tout" em 2001 para fazer parte do catálogo da exposição fotográfica de Clément Chéroux, "Memória dos campos", onde entra em defesa das imagens como únicos totográfica de Clément Chéroux, "Memória dos campos", onde entra em defesa das imagens como unicos testemunhos visuais do genocídio, que devem ser compreendidos a partir de suas precárias e perigosas dos campos na épça.

Letrônica | Porto Alegre, v. 12, n. 3, jul.-set 2019: e33501 também essa espécie de "lugar apesar de si", lugar impossível de apropriação e de assinatura, que concerne a todos. A história do Holocausto escapa das mãos dos sobreviventes para pertencer igualmente a todas as gerações futuras. Como escreve Marguerite Duras em seus cadernos da Segunda Guerra publicados sob o título $A$ Dor (1985), o crime não cabe mais a uns ou a outros, e nem a experiência. É necessário partilhá-lo, carregarmos todos, nos ombros, seu peso histórico.

Eis então uma dolorosa partilha. O lugar apesar de si é esse que constitui "nosso próprio presente reminiscente, na história - sempre mutante, sempre a requestionar, sempre a reformular - de nossa relação com a história" (DIDI-HUBERMAN, 2014, p. 25). 0 lugar apesar de si é também um lugar apesar de tudo, mas que encontra seu espaço no entrelaçamento da tomada de palavra pelo homem da sobrevivência com a imaginação daqueles que integram e partilham de seu testemunho. Se o lugar apesar de tudo é o rasgo, o lugar apesar de si é o que possibilita habitar esse rasgo enquanto partilha de uma história em infinita reformulação.

Creio que não há como prosseguir por esse mapa conceitual ensaístico de Didi-Huberman sem lembrar de Theodor Adorno e suas considerações sobre a impossibilidade da poesia após Auschwitz. Lendo Adorno na chave hubermaniana, diremos que a poesia só é possível após Auschwitz ao mesmo tempo que carrega a memória dos campos. Para melhor elaborar, toda poesia após o Holocausto o encarna, o incorpora, não pode ser poesia sem que partilhe desse passado que pertence a todos. "Esses traços outrora familiares de nossa civilização [...] fazem parte integrante de nossa vida. Não desapareceram no ar" (DIDI-HUBERMAN, 2014, p. 30).

Em Essayer Voir (2014), Didi-Huberman evoca a obra do artista polaco Miroslaw Balka para retomar o diálogo entre os lugares e as imagens dialéticas. Sobre a obra de Balka, Zygmunt Bauman afirma ser uma forma de escutar o passado, mas também de lhe falar. Por sua vez, Balka, em entrevistas sobre suas montagens, afirma que tudo o que tocamos vem do passado, e constitui, assim, nosso acesso à morte. 0 presente é, por essa lógica, um quadro de reminiscências de um tempo anterior, representando uma estrutura fraturada, craquelada, heterogênea. Assim, em relação direta com o que elabora pelas páginas de seu ensaio, Didi-Huberman analisa que obra de Balka inventa superposições e fraturas que fazem dialogar com a heterogeneidade dos tempos, sendo ela também um rasgo, para pensar na palavra trazida pelo filósofo em seus livros. A potência imagética que Balka concebe é aquela 
que toca o tempo: "Tocar o tempo, isso que pode uma imagem, à condição de ser "dialética", à condição de organizar com justeza suas mônadas e suas montagens" (DIDI-HUBERMAN, 2014, p. 36-37, grifo do autor.).

Figura 1 - Miroslaw Balka, Apple T.

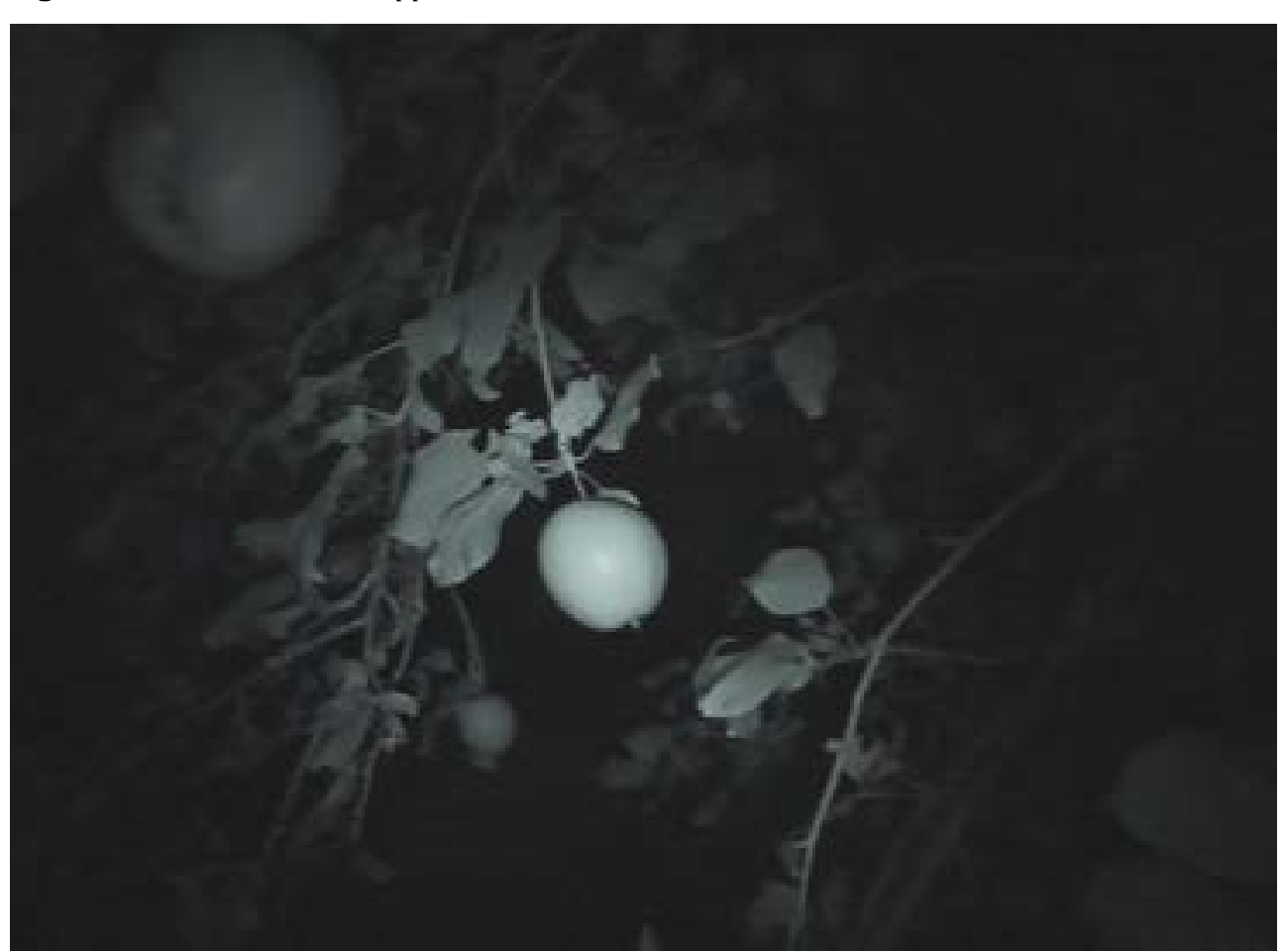

Fonte: Imagem extraída do site Contexts ${ }^{6}$

Suas instalações comportam vídeos, fotografias e esculturas que incorporam movimentos e fios temporais, capazes de amalgamar histórias e temporalidades diversas, remetendo à infância do artista como um momento passado que é pulsante no presente. Didi-Huberman reconhece a obra de Balka como centrífuga,

Disponível em: http://www.contexts.com.pl/en/artists/miroslaw-balka. Acesso em: 3 mar. 2019. por se abrir da memória infantil para uma memória fraturada, coletiva, "apesar de si". Eis Balka para o ensaísta: um artista que rasga o presente com alguns traços ou espaços da memória histórica, que divide e inquieta os lugares de cultura - os museus, os salões de arte, por exemplo - com aquilo que eles retêm dos lugares da barbárie - da crueldade, da violência, da brutalidade que ali são incorporadas. E, ainda, como não olhar sua Apple T. e não lembrar da macieira de Appelfeld? Ambos partilhando de uma imagem de um lugar apesar de tudo, e também apesar de si, tão semelhante e tão singular ao mesmo tempo?

0 artista é o epítome do que Didi-Huberman procura defender como o movimento do "olhar": o olhar como se abrir, como fenda no tempo, para rasgar o tempo que a linguagem une, "rasgar a linguagem mesma" (DIDI-HUBERMAN, 2014, p. 49). A obra de Balka é aquela que perpassa um olhar inquietante, olhar de "rasgo", que destarte é capaz de desarticular o tempo e a linguagem que o pretende uno. Diante de sua obra, uma sensação de subtração é, portanto, experienciada, já que o tempo é quebrado e a linguagem é partida. 0 ato de olhar, para Didi-Huberman diante da imagem artística, seria então abraçar a experiência de nada conseguir de estável. Aceitar perder o norte das palavras diante da imagem. "Aceitar a impotência, a desorientação, o não saber, por ser aí que reside justamente uma nova chance para a palavra, para a escrita" (DIDI-HUBERMAN, 2014, p. 52).

0 artista é capaz de criar com sua obra uma imagem dialética que permite não somente o acesso a uma história turbilhonada em sua origem, mas também a partilha do tempo fraturado que essa história abarca. Isso posto, Balka é aquele que, construindo com sua arte um "lugar apesar de tudo", descerrando suas memórias e arquitetando um "lugar apesar de si", nos convida à "partilha". Mais ainda, diante de suas imagens, somos convocados à olhar, não no mero ato de "direcionar os olhos" como prevêem os dicionários, mas no movimento de abertura que permita o reencontro com a palavra.

Faço, diante da obra inquietante de Didi-Huberman e de suas considerações sobre Balka, outra pergunta, que de certo modo já foi respondida ao longo dessas páginas: por que essayer voir? Falei sobre a estranheza que a transitividade da frase carrega na língua francesa. A fonte em que o autor foi beber para esse título foi Samuel Beckett, o qual realiza o mesmo jogo com os verbos "tentar" e "dizer". Para o dramaturgo, essayer dire (cuja tradução poderia ser também "ensaiar dizer", ou "ensaiar o dizer", seguindo a tradução proposta no começo desse texto) 
é o ato que corresponde ao movimento dos yeux clos écarquillés (olhos fechados arregalados). Cito Didi-Huberman analisando a expressão do dramaturgo:

Ele responde pela indicação de um gesto duplo ou dialético, que remete ao gesto de ir e vir das pálpebras, constituindo a expressão "olhos fechados arregalados". Olhos fechados para não crer que tudo será ao alcance como material integral à vista nua [demonstrativo ad óculos]. Olhos arregalados para se abrir e se oferecer à irresumível experiência do mundo. E olhos cerrados arregalados para enfim pensar, e mesmo para dizer, para ensaiar dizer isso tudo junto. Se a linguagem nos é dada, o dizer nos é constantemente retirado, e é pela luta de todos os instantes, um ensaio sempre a recomeçar, que nos debatemos com esse inominável de nossas experiências, de nossa falha constitutiva diante da opacidade do mundo e de suas imagens (DIDI-HUBERMAN, 2014, p. 53, grifo do autor.).

O convite que Didi-Huberman nos faz desde seu título é, portanto, uma chamada a um movimento ensaístico. Diante de uma imagem e de suas perguntas não respondidas, de sua opacidade, de suas fraturas que nos subtraem a linguagem, nos cabe "ensaiar o ver", ou seja, abraçar a instabilidade e permitir que o não saber seja a porta de entrada para um novo encontro com a palavra. Pois só "ensaiando o ver" que poderemos "ensaiar o dizer" diante da imagem. "Ensaiar o dizer [perante a imagem]: não querer julgá-la, não a determinar a um lugar definitivo na hierarquia dos valores da história, mas fazer derivar forças que ela nos traz para transformar - experimentalmente - nossa própria linguagem e nosso pensamento diante dela" (DIDI-HUBERMAN, 2014, p. 72).

"Ensaiar o ver" anseia para que as coisas não sejam vistas nem ditas, mas para que estejam sempre por ver e por dizer. A história da nossa relação com a história perpassa um contínuo "ensaiar o ver", um a cada vez "ensaiar o dizer". Para o autor, interessa manter o movimento, a inquietação, a heterogeneidade para que se partilhe do testemunho e da construção da imagem dialética. E se, nesse livro, ele "ensaia o dizer" no campo da conceituação, com uma linguagem mais técnica, em Cascas (2017) o que lemos é o momento do "ensaiar o ver" e o "dizer" transformado em narrativa. É o contato de Didi-Huberman com um "lugar apesar de si" ao entrar nesse "lugar apesar do homem" que é o campo de Auschwitz-Birkenau.
Retornando à Cascas, uma nota encabeça a primeira página do livro: "Memória: Sob as árvores de Auschwitz-Birkenau, o olhar arqueológico torna evidente o horror pulsante que o museu institucionaliza como História". A História com H maiúsculo que é cristalizada pelos campos tornados museus será uma problemática aos olhos de Didi-Huberman, por ir contra à história sempre a ser contada e reaberta que o autor defende enquanto imagem-dialética. Fechada à possibilidade de partilha, o museu Auschwitz-Birkenau parece fundar um lugar de cultura sobre o lugar de barbárie, em uma perigosa arquitetura apoiada no horror e em sua fundamentação enquanto imóvel e encerrado passado histórico.

Em cautela quanto à História, rastreando as fraturas do tempo na imagem, ele nos fala de um "olhar arqueológico", que permite "ensaiar o ver" perante as imagens que encontra, e mais ainda, percebê-las enquanto frutos de entrecruzamentos temporais, em sua dialética. Como aplicar tal olhar ao observar, por exemplo, a fotografia da página seguinte, tirada por ele? É o que ele mesmo explica na citação que a antecede, que recorto abaixo:

É de fato esta estrada, este caminho, são de fato estas duas cercas de postes de cimento e arame farpado. Apesar de agora vazio de todos os atores de sua tragédia, este é claramente o lugar de nossa história. 0 fogo da história passou. Partiu como fumaça dos crematórios, soterrado junto com as cinzas dos mortos. Isso significaria que não há nada a imaginar porque não há nada - ou muito pouco a ver? Certamente não. Olhar as coisas de um ponto de vista arqueológico é comparar o que vemos no presente, o que sobreviveu, com o que sabemos ter desaparecido (DIDIHUBERMAN, 2017, p. 41). 
Figura 2 - Lagerstrasse A

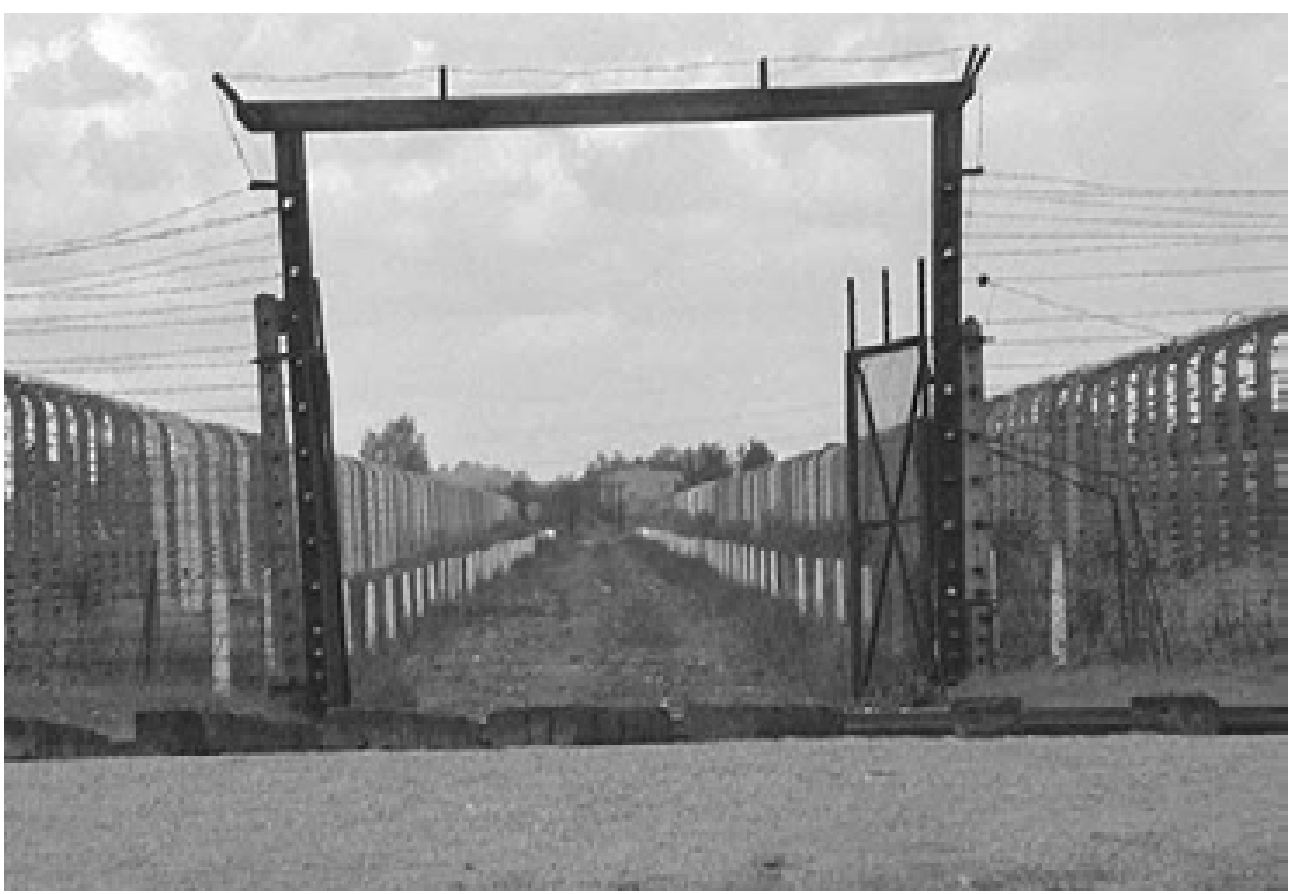

Fonte: Imagem extraída do site Remember?

Não à toa sua narrativa é marcada por perguntas. 0 olhar arqueológico que aplica às imagens vai em direção ao desvendamento das temporalidades jamais estáticas entre a barbárie e a cultura. Trata-se, relembrando uma expressão utilizada pelo autor em $O$ que vemos, o que nos olha (2017), de inquietar o ver, mantê-lo em fluxo de questionamento, nunca estático, para que se tente perceber o que escapa ao olhar comum. Somente por esse esforço lhe foi possível alcançar que "Auschwitz como Lager, lugar de barbárie, sem dúvida foi transformado em lugar de cultura, Auschwitz 'museu de Estado'” (DIDI-HUBERMAN, 2017, p. 34).

Disponível em: https://remember.org/educate/b2mg0007-2. Acesso em: 3 mar. 2019.
Didi-Huberman quer provocar em nós, naqueles que se detém diante de uma imagem, uma comichão necessária para que se "ensaie o ver". Contra o adormecimento das temporalidades pulsantes que carregam as imagens dos campos, ele entra em defesa dessas mesmas imagens "apesar de". Apesar da violência, da barbárie, do choque, do golpe, do horror, são "imagens"; fazendo referência ao livro homônimo, são "imagens apesar de tudo", que nos interpelam e convocam à uma nova relação de partilha da história e de tomada da palavra. Defender imagens como são, em sua potência, é defender a capacidade e o direito de "partilha" e de "imaginação" que temos como habitantes de múltiplas temporalidades históricas.

0 chão de Birkenau, dilacerado pela história, que berra o horror que abriga em seu rasgo, atravessa o narrador-ensaísta em toda sua potência atemporal. Mesmo diante da espécie de maquiagem utilizada para, de certo modo, transformar em arquivo de museu o tempo de barbárie, o massacre realizado naquele ambiente densifica toda sua aura. 0 amigo que o acompanhava na visita, Henri, lhe diz, como escuta-se geralmente dizer quando diante de uma realidade insuportável: "isso é inimaginável" (DIDI-HUBERMAN, 2017, p. 30) E sua resposta, a resposta de alguém cujo olhar arqueológico está sempre por ensaiar-se, é a seguinte:

Mas, se devo continuar a escrever, ajustar o foco, fotografar, montar minhas imagens e pensar isso tudo, é precisamente para tornar uma frase desse tipo incompleta. Cumprira dizer: 'Isto é inimaginável, logo devo imaginá-lo apesar de tudo' (DIDI-HUBERMAN, 2017, p. 30).

Cascas (2017) é, portanto, um "lugar apesar de tudo", onde se imagina "apesar do horror", onde se ensaia o ver e o dizer "apesar do choque". Sua narrativa em primeira pessoa chama a sair do impasse do ver, desse impasse da imaginação que foi, segundo o autor, força estratégica, via mentiras e brutalidades, do sistema de extermínio nazista. Tentar ver - tentar dizer frente ao inimaginável, ensaiar esses dois movimentos apesar de tudo, construindo um lugar apesar de si, é fazer da dor e, logo, da memória e da história que as acompanham, um tecido em eterna reconstrução e em partilha. 0 olhar de Didi-Huberman ao campo Auschwitz-Birkenau é o olhar inquieto e dialético que defende nos movimentos do que chama de ensaiar o ver, e seu testemunho é escrito na trilha do "homem de sobrevivência”, aquele que é capaz de tomar a palavra apesar do horror. 0 "lugar 
apesar de tudo" é a própria narrativa de Cascas, e o autor observa - e é observado por - Auschwitz em sua origem-turbilhão, no encontro de suas temporalidades.

Em uma frase de Cascas (2017), lemos: "a verdade não é dita com palavras, e sim com frases" (2017, p. 41). Lendo a mesma frase na perspectiva de Essayer Voir (2014), digo que a verdade não é dita com mônadas, e sim com montagens. A verdade da imagem, do testemunho, não configura uma experiência pura, construída a partir de uma origem-fonte, mas de uma origem-turbilhão, sempre em movimento dialético, inquieta, no ver e no dizer que estão sempre por vir. Seja a partir de uma escrita objetiva e de cunho filosófico, seja através de uma narrativa em primeira pessoa de caráter testemunhal, o convite que o autor nos faz em seus ensaios é o mesmo. Ele nos chama à partilha de uma história em construção e reconstrução, cujas imagens tecem a escrita dos tempos.

É necessário imaginar, portanto. Imaginar, fotografar, escrever, criar, narrar, construir: para que se sobreviva, para que haja partilha e para que uma História única não se sustente. Diante da imagem, "ensaiar o ver" é a questão do cada um de Lemaire (2008, p. 33): "Cada um caminha curvado, /procurando em si próprio/a flor que falta". E a tentativa de "dizer" e "ver" apesar de, de não se deixar capturar pelo emudecimento, e de partilhar do jardim da memória com um aguçado olhar arqueológico. Em ambos os textos, Didi-Huberman nos convida a "ensaiar nosso ver", para que, diante da origem vertiginosa das fraturas do tempo, diante da arte que rasga as noites de barbárie, diante do horror emudecedor de uma imagem e na instabilidade de uma linguagem que escapa, possamos tomar a palavra e sobreviver.

\section{Referências}

ADORNO, Theodor W. Dialética Negativa. Trad.: Marco Antônio Casanova. Rio de Janeiro: Jorge Zahar Ed., 2009.

ALLOA, Emmanuel. La pensée phasme. Revue Europe, Paris, n. 1069, p. 68-78, maio 2018.

BARRENTO, João. O gênero intranquilo: anatomia do ensaio e do fragmento. Lisboa: Assírio e Alvim, 2010.
BENJAMIN, Walter. Origine du drame barroque allemand. Paris: Éditions Flammarion, 2009.

DIDI-HUBERMAN, Georges. Cascas. São Paulo: Editora 34, 2017.

DIDI-HUBERMAN, Georges. Essayer Voir. Paris: Éditions de Minuit, 2014.

DIDI-HUBERMAN, Georges. Libres yeux de l'histoire. Revue Europe, Paris, n. 1069, p. 18-30, maio 2018.

JORGE DE OLIVEIRA, Eduardo. L'exposition comme espace de pensée. Revue Europe, Paris, $\mathrm{n}$. 1069, p. 146-152, maio 2018.

LEMAIRE, Jean-Pierre. FIgure Humaine. Paris: Éditions Gallimard, 2008.

LEVI, Primo. É isto um homem? Rio de Janeiro: Editora Rocco, 1976.

PIC, Muriel. Qu'est-ce que s'orienter dans les images? Revue Europe, Paris, n. 1069, p. 3-17, maio 2018.

SOMAINI, Antonio. Montage et anachronisme. Revue Europe, Paris, n. 1069, p.54-66, maio 2018. 